be found of improvement. Of course, it would be necessary to administer the anæsthetic with the utmost care, bearing in mind the nature of the disease. Abdominal section has frequently been credited with temporary arrest of tuberculosis of that cavity. May not ether be the chief factor in the temporary arrest? I am, Sirs, yours faithfully, Sept. 5th, 1907. ROBT. HUGH HODGSON.

\section{THE SEASONS AND MENTAL DISORDERS.}

To the Editors of THE LANCET.

SIRS,-The incidence of mental disorders does not correspond in point of time with recorded admissions into asylums, especially private asylums. It is true that the summer months, as indicated by Dr. J. Adam, bring special anxieties and maximum work, for suicides are most common in July and least common in November; but the inception of these disorders must be referred to the spring months, as I have shown in the Morison lectures of this year. It is undoubtedly in the study of the prodromal period and the onset of insanity that modern methods of treatment must find their bases and most hopeful development.

I am, Sirs, yours faithfully,

Perth, Sept. 7th, 1907. A. R. URQUHART.

\section{TUBERCULOSIS IN SPAIN.}

\section{To the Editors of THE LANCET.}

SIRs, - I am informed that after a fatal case of bacillary phthisis it is the national custom in Spain to disinfect and redecorate the room in which the fatal case occurred. Can you, or any reader of THE LANCET, inform me if this is a fact? I am, Sirs, yours faithfully,

Cornwall,"Sept.:2nd, $1907 . \quad$ C. E. ABBoTT, M.R.C.S. Eng.

** It is a fact that tuberculosis is regarded in Spain as very infections. It is difficult to let a house or rooms in which a patient has died from this disease. Moreover, the furniture is generally destroyed after the death.-ED. L.

\section{THE GUILD OF ST. LUKE.}

\section{Io the Editors of THE LANCET.}

SIRS,-May I draw attention to the advertisement appear ing in the present issue of THE LANCET respecting the annual festival service of the Guild of St. Luke to be held at St. Paul's Cathedral on Oct. 22nd and request that those who desire to attend will communicate with me as soon as possible; as we are expecting a large attendance from the City companies and others we are anxious to allot space as soon as possible. I am, Sirs, yours faithfully,

ClaUde ST AUBYN-F ARRER, 7, Westbourne Park-road, London, W., $\quad$ Registrar. Sept. 9th, 1907.

\section{TEA SHOPS AND DUST.}

\section{To the Editors of THE LANCET.}

SIRS,-May I draw your attention to the practice that seems to me insanitary and otherwise objectionable of sweeping the floors of tea shops while customers are eating and drinking. I admit it is not done during the busiest time, bnt I have just been suffering from it in one such shop at 2.40 to-day. A word of condemnation in your columns would go far to suppress this nuisance.

August 22nd, 1907 I am, Sirs, yours faithfully,

\section{THE ROYAL SOCIETY OF MEDICINE.} 70 the Editors of THE LANCET.

SIRs,-The usual annual issue by the editors of the Medical Directory of slips for correction will perbaps place others of your readers, as it has myself, in a little difficulty as to how they should describe themselves in connexion with the Royal Society of Medicine. I believe that a Fellow of the late Royal Medical and Chirurgical Society ipso facto becomes a Fellow of the new Royal Society, but how is my partner to replace his "Fell. Obst. Soc.; Mem. Clin. and Path. Socs." ? and how is one who previously belonged oniy to the Clinical Society to write himself down?

Sept. 9th, 1907.

I am, Sirs, yours faithfully,

PuzzLend.

\section{THE PUBLIC AND PRIVATE SLAUGHTER- HOUSES OF DUBLIN.}

(From our SPECIAL SANitaRy Commissioner.)

PART I.

The Public Abattoir.

THE position of Dablin in regard to its slaughter-houses, public and private, is peculiar and somewhat perilous. Under existing conditions there can be no serious guarantee that the meat is properly inspected before it is sold for human food. On the other hand, the complications that have arisen are such that it is not easy to see how matters are to be arranged in a satisfactory manner without occasioning a good deal of friction and opposition. To put the case briefly, there were many private slaughter-houses in existence when the Dublin Improvement Act of 1851 became law. Since that date licences for slaughter-bouses have been frequently granted, although they were accompanied with the stipulation that on the establishment of a public abattoir these private slaughter-houses should be given up. Ultimately a public abattoir was built, but it was placed on the county side of a road which divided the county from the city of Dublin. Thereupon the butchers contended that as the abattoir was not within the city they could not be made to go there and need not give up the temporary licences that had been granted to them on the conditions explained above. Either the butchers were right in law or the authorities supine in the matter, for the butchers were not forced to close their private slaughter-houses. In 1890, however, another Dublin Improvement Act was passed and then the boundaries of the city were extended, so that now the public abattoir is within its jurisdiction. In these circumstances it was naturally thought that the private slaughter-house licences would, as originally intended, come to an end. These, however, are technical matters. They do not come within the scope of popular, political, or theological controversy, and the great mass of the people at Dublin are not taught to study such purely practical and scientific problems. Therefore the handful of butchers who have a personal interest in the question are often able to act as if there were no other interests than their own to consider, because public opinion is too ignorant or too indifferent to exercise any check. Thus interested parties were able to bring influence to bear, so that the corporation of Dublin during the passing of the Act agreed to regard as permanent the temporary licences which it had granted. Instead of coming to an end automatically when the boundaries of the city were extended and included the public abattoir it was now stipulated that these licences could only be extinguished by purchase. Yet it cannot be said that these butchers had a vested interest since the licences were only given as temporary licences. It was known from the first that the butchers would be called upon to remove their slaughtering business to a public abattoir ; nevertheless, the ratepayers are now to be called upon to give them compensation. But this is not all, for even if the money is forthcoming another difficulty arises. The Act insists that only one person can receive compensation in regard to the closing of a private slaughter-house and it is often a matter of great perplexity to determine who that one person should be. Thus it is that since the passing of the Act in 1890 only 18 private slaughterhouses have been closed, and, including some situated in three townships recently annexed to the city, there still remain in Dublin no less than 62 private slaughter-houses.

That it is necessary to do away with the private slaughterhouses can scarcely be questioned; it can only be urged that their abolition should be deferred till a very much better public abattoir is built than that which now exists. The situation is described by Surgeon-Colonel D. Edgar Flinn, medical inspector of the Local Government Board of Ireland, in his official report for 19C6. He there states that about 70 butchers avail themselves of the public abattoir, killing there from 700 to 800 animals weekly. The average number of cattle slaughtered weekly is about 200 , of sheep 450 , of pigs 50 , and of calves 6 . On the other hand, the killing in the private slaughter-houses is approximately estimated at cattle 380 , sheep 1671 , pigs 739 , and calves 20 . Thus only about a quarter of the slaughtering takes place at the public abattoir; by far the greater part of the Dublin meat comes from private slaughter-houses. Many of these private slaughter-houses 